\title{
$\langle 3$ The Pedagogical Atmosphere: The Perspective of the Child
}

\author{
Otto F. Bollnow
}

University of Tübingen

\section{The Atmosphere of Security}

\section{The Trust Toward the Mother}

The foremost precondition for a pedagogical atmosphere is the existence of a sheltering environment of the home and the family from which the supportive feelings of trust and safety can radiate. Trust is a prerequisite for all healthy human development. Only in an atmosphere of security can the child grow in the right direction, and only in this medium does the world reveal itself to the child in all its reasonable order. Should this atmosphere of security be missing, then the world remains a shocking, threatening, encroaching power. And if this sense of security is not guaranteed elsewhere, then the child is refused the will to life, and he or she withers emotionally.

This world is, of course, not even from the beginning, the whole world. Rather, it is only a narrower and trusted region within it. In the distance, behind this atmosphere of security exists another foreign and threatening domain. We know from many poetic descriptions of childhood, especially impressive in the works of Hermann Hesse (for example in Demian), how sharply contrasted the world of the familiar and trusted (the world of good) from the other world of the threatening, the darkening, the unfamiliar (the world of evil) is for the child. But the integrity of this inner world of security and its distinct separateness from the other world continue to be the indispensible conditions for healthy development of the child.

It seems that such a trusted and sensible world reveals itself to the child fundamentally only in the trusting relationship with a certain beloved other person, in the first instance usually the mother, so that from the start, the common tone of security is tied to a specific situation of a single beloved person. Therefore, from the relation with an individual beloved person arises both the world and the characteristic of trust and accomodation. Whatever belongs to the world of the mother, whatever is touched by her, is included in this bright realm-it is good! But whatever she rejects remains bad, and one must be cautious of

Phenomenology + Pedagogy Volume 71989 
that. Thus the sharp contrast between good and bad comes into existence. For instance, my little daughter asked me each time she saw a picture of a stranger, for example, a politician in the newspaper, "Is he good?" and only after an affirmative answer was she contented. Without this answer, the presence of a strange picture in the trusted home would have been a disturbance.

Pestalozzi (1927) has described in an unsurpassed manner how the child must acquire trust early in his or her relationship with the mother or father. Only in the presence of the parent does the young infant feel safe. When an unfamiliar object frightens the infant, Pestalozzi writes, and as soon as the child begins to cry, the mother tends to take him or her in her arms and smile at the child. The infant returns the smile of the mother with bright, unclouded eyes, and thus the seed of trust is sprouting in the child. This trust then continues in the growth of the child's world, includes more and more people, and from this first seed of trust, according to Pestalozzi, all the other feelings of this young person's unique nature gradually unfold.

Nitschke (1962) has, from the standpoint of a pediatrician, presented in an impressive way the significance of trust in early child development and with this has also revealed its fundamental importance for pedagogy in general. I want to try to blend his insights into the normal pedagogical perspective. But even here I should refer to his own words. "The mother creates through her caring love for the child a space of trustworthiness, of dependability, of purity. What is found in this place seems to belong, to have sense, to be alive, trusted, close, and approachable" (p. 13). Only the parent's love-and in later years the common trust of other caring adults-draws around the child the signs and symbols of the world of trust, and raises it as a glowing region against the background of darkness and mystery. Nitschke continues, "From this arises the powers of insight which make possible the child's approach to the world, to people and to things." Only by way of trusted people do things present themselves.

In the same vein the poet Rilke (1930) writes in the "Third Elegy":

Mother ... you arched the friendly world

over his new eyes and shut out the strange one ...

You hid so much from him this way

rendering harmless the room that grew suspicious at night

and from the full sanctuary of your heart

you mixed something human in to this nightspace. 
Thus mother humanizes that which is strange in the darkness of the night-room and removes the threatening invasion of what is unfamiliar. She makes it harmless.

\section{The Expansion of the Circle}

As the world changes, the character of security in the course of human development changes as well. In the beginning the child is gathered in the closeness of the nest, if we may apply this analogy to the life of the child. The child lives in his space in unquestioned safety. The child's gaze does not yet view beyond this space into the larger world. This is the budding, slumbering form of life as Arndt (1912) has so nicely drawn it:

Life and dream still one:

I was rocked in both

the crib of love. (p. 26)

In this quiet realm the strange world only appears from a great distance-as over a fence--part threatening, part beckoning.

When children begin to stir themselves and venture out into this world, they do it at first at the hands of their parents, trusting all the while in their parents' ready help and power. At this stage children appear blissful, and for parents it may often be rather embarassing how far the trust goes. For the child, mother and father are omnipotent, and the child feels secure in their care. Even when the belief in omnipotence is relinquished, mother and father are still those who can do almost everything best and who know what is best. One of my children said once, "You are called father because you make everything well. You fix everything." This statement hits the core of the matter, for it was not just my unlimited competence with handiwork that was here (quite undeservedly) attributed to me, but also the quiet belief in my ability to heal anything, the ability to make whole anything that is damaged and broken, to reintegrate the dissolving world. Nothing more is meant by the common children's song, "Heal, Heal, Blessing" which mother hums when the child has hurt himself or herself and is heartbreakingly crying. Here, too, we see the trust in the parents and their magical powers before whose healing works all a child's sorrows vanish.

Later the familiar conditions change when the teacher, as a new and more highly respected person in the child's eyes, takes over the place of the parent. Now the teacher may have become the final authority and naturally knows everything better than father. I am reminded of the unsolvable confusion my son experienced in his first year of school when he found that his most admired and wonderful teacher had been my student and was still learning herself. This did not fit his sense of the order of 
things. But even if the source of the child's trust and admiration has shifted to someone else, to the teacher and no longer to the father, even then the fact remains that there will always be such an embodiment of omniscience in the child's world.

It is easy to laugh over such childlike sentiments, but these distortions of the "objective" world have a deep significance in the limited perspective of the child. They are the expression of the special function of the trusted person within the child's world and this function is of greater importance the younger the child is. Pestalozzi (1927) saw this deeply in his time: Mother is the embodiment of the Absolute for the child. Even more strongly, both the Absolute and the living objective person fuse here and are separable only later in the child's development. This relationship is of fundamental significance for the understanding of all human development. It means, on the one hand, that the Absolute is first comprehended in the form of the mother or the father and that all later additions are screened through this original experience; that is, things are excluded if they do not conform to this early form. But over and above fulfilling the function of the Absolute for the child, the parent must also give him or her an unconditional footing and a lasting refuge in this confusing world.

This usually does not apply as much to the father because he often appears more fully only at a later stage in the child's life. In such cases, the pedagogical function of the father is less clear than the mother's. But eventually, even the father comes to embody the Absolute, the almighty, and the all-knowing for the child, sometimes even at a certain level above the mother.

\section{The Breakdown of the Atmosphere of Security}

From this follow far-reaching and seldom fully understood pedagogical consequences. These impulses of a child's trust require special and cautious care, even when, from the perspective of the adult, these impulses appear excessive, for this trust is truly a foundation that must exist if the child is to develop properly. It is also an essential condition for the task of childrearing. This care, in relation to the changing needs of the developmental phases, advances in a dual direction. On the one hand, the unconditional trust in mother and father is to be continued as long as it faithfully contains the child's world and presents continuing possibilities for the child. Never should it be torn asunder with bare hands so that the child "falls out of the clouds," as it were, and becomes disoriented with irreparable damage. On the other hand, the unconditional trust must necessarily break apart as soon as the child takes on 
some independence and notices inadequacies in even the best, most helpful person, for a person who is essentially imperfect cannot fulfill this function forever. People are not gods, and the child eventually experiences their human weaknesses. Nitschke (1962) makes this quite clear:

The trusted and protected world carries from the beginning the seeds of its own transition. In fact, the totality of this trust is the grounds for its demise, for at some time the insight into mother's imperfections must break through. With this knowledge ends the completeness of the child's world. (p. 15)

Other difficult questions arise for bringing up children, to which Pestalozzi has already directed his attention in the previously mentioned letters. What is required of the parent or teacher here? Their task is to guide the child carefully through the disappointments in order to slowly and carefully allow him or her to leave behind the absoluteness of trust in one concrete other person, and to guide to a new state, no longer bound to a single person, which provides a firm support against all other possible disappointments of life. The central task is to create a space for such trust, which will form the ground of a sense of security in spite of all calamities and all threats. The child must be able to perceive the possibility of a sound world because without this basis no human existence can stand. And where this trust is omitted one may expect the occurrence of inner and outer disintegration. Also, in this realization resides the fundamental problem of a religious upbringing. Above all one must guard aginst the simplistic notion that suggests that the breakdown of the early form of security makes it possible to arrive at a new form of security (Bollnow, 1955). The erosion of the child's security remains an endangering condition. Let us refer once more to a formula of Nitschke $(1962$, p. 10): There exists a duality of fear and trust, into which, unto the highest age, human life is placed, or as Jacobi called it, "an alternating song between heaven and hell." Forever anew must the realm of security be won from the invasion of counter influences.

\section{The Lasting Significance of the Atmosphere of Security}

But we are getting ahead of ourselves, for we are talking about events which, only stepwise and through differing levels, continue throughout the life of a person and are completed only in adulthood.

Let us concern ourselves for the present with the young child. Here our aim is to protect the continuity of development and to avoid sudden disturbances. Even if the early childlike form of absolute trust has been lost, the pervasive basis of trust has not 
simply disappeared. It continues more often in other, more limited forms, and these must also be attentively cared for. The educator or parent must be cautious not to dismiss flippantly this trust, and he or she must forever strive to recapture the lost sense of trust. The success of child development remains unremittingly linked to a sense of trust in the parents and in the existing order of things. Pestalozzi (1927) writes about the difficulties of his attempts with the neglected and distrustful children he met in Stans: "Above all I wanted and needed to win the trust and attachment of these children. Grant me these and I could expect everything else from them" (p. 8). This really is the decisive foundation. What was initially included in the unlimited trust which the child feels toward one special person is later replaced by a less absolute sense of trust in life. In other words, the original trust invested in a single person has now become a more generalized sense of trust in the world.

The quality of security of the relationship which we maintain with other people is related to the quality of protectedness we feel in a sheltered domain. Even if the unconditional trust in the protection of mother or father is lost some day, and lost it must eventually be, still the significance of a felt sphere of trust remains - even if it no longer has quite the unconditional character as before. And so it is always the task of childrearing to create for the child this realm of security and then to guard it, even if it is no longer tied to a certain single person such as the mother or father. Despite the fact that intrusions by threatening events will occur, it remains true that the child can properly develop only in an environment which is relatively clear, orderly, and predictable. Of course, if the adult is convinced that the world is fundamentally frightful and threatening, then the task of creating an island of security in which the small child can develop in safety to the point of being able to meet the forces of raw reality may be hampered.

The requirement of a sense of security cannot be fulfilled because we are talking here about the basic laws of child development. Comenius understood this. Although for him the world was a terrible labyrinth, he placed great value on the idea that child development be carried out in the context of an orderly world. Frobel (1951), too, considered the notion of an all encompassing sense of meaningfulness the foundational idea for raising children. This concept is still sound and unsurpassed by any other insight, even though Frœebel's romantically grounded conviction of a harmony of the world has long shown itself to be untenable. Indeed, one can turn his theory upside down: The more the world is experienced by us as dreadful, the more 
urgent it becomes not simply to deliver the unprepared child into this undesirable world; rather, the task becomes to create around the child a sphere of an ordered and meaningful world in which the child can grow and develop, so that as an adult he or she will be able to survive in the larger and harsher world.

Even when the child's "life-circle" gradually expands, the necessity for such a sphere of security continues for all later development. It is in the nature of the process of growing up in the wide and ever widening world that the child has increasingly less space in which he feels secure and into which he or she can withdraw if he or she has ventured too far. The adventurous explorations of young boys, like the ones described by Frcebelthe joy of climbing mountains and crawling in caves, this entire play with things unfamiliar and dangerous-are only possible if there exists an awareness of a safe refuge in the background to which the child can withdraw if necessary. That is why we must cultivate this feeling of security in a trusted realm, even if children at certain stages of development do not seem to value it.

Gradually this protected realm liberates itself from the connection with adults. It is no longer just sought by the child, rather it must be built by him or her. Out of what is given at present arises a challenge. The first foreshadowing of this challenge comes at an age when the child feels the need to create his or her own hiding place-the secret space of which Langeveld (1954) speaks. I have experienced this small den which my daughter built at a certain age, together with a friend, and about the very existence of which no one was supposed to know. From this emerges the later desire of children to arrange their room so that they feel it is their very own. In this way children express the need to make their own room a haven of security for themselves-a need which adults must be able to understand and support. We should not be too upset if this remodeling may lead to some damage (as with hammering in nails) or if it leads to disturbances in the normal order of living, for something is being prepared here which has consequences for the child's maturation. Even when, over time, the child's view of life is realigned and the child develops greater interest in the outside world, the relationship between the strange world of the outside and the protective world of the inside is maintained as a stable foundation for human living. The emotional health of the person remains dependent on having a space in the home to which he or she can withdraw, feel secure, and be sheltered from the disturbances and threats of the larger world. It is the place where one can truly be oneself (Bollnow, 1963). 
The need for a realm of security is true for all human living. It is true for adults but especially for children who, because of their age and level of maturity, may feel more vulnerable, helpless, or dependent. Thus it is the responsibility of adults to permit or create opportunities for children to be able to experience a sense of security in the space of the inner realm. It allows growing youths to feel right about their lives, regardless of their need to protest, challenge authority, or disturb established relations.

\section{The Emotional State of the Child}

\section{Cheerfulness}

We now explore the initially all-pervasive sphere more closely. First there is the assumption that young children need the feeling of a carefree cheerfulness which, like a universal and pervasive emotional foundation, must enfold and encompass the young life if it is to unfold itself freely and if it is to open itself onto the world. This assumption rests on the universal significance of the mood for human living. The concept of mood is in no way to be understood as a mere play of interchangeable illuminations which lightly brush over the soul without affecting its existence in any significant way. Rather, mood is, as we have known since Heidegger (1927), the universal ground from which life and the world develops as it colors the everyday existence of the person. Mood is the fundamental substrate which allows the possibility of all individual conceptions and modalities of living and the world to arise. It is important to reflect on the significance of mood in life because it makes it possible for us to understand the fundamental oppositions between joy and sadness, upliftedness and depression. These moods express in their polarities the fundamental contrasts between which all the manners and behaviors of human beings are located. Under the spell of dark and gloomy moods, life becomes cheerless and the person withdraws within himself or herself; he or she encapsulates the self within the self and loses contact with the outside world. In this mood all the powers of growth are suppressed. In the experience of sorrow the person becomes wretched in every sense of that word, much like a plant that longs for light. Conversely, the joyful mood opens the person again to the world. Joy leads the person to gain interest in his or her surroundings and so experience joy in his or her own activities. The mood of joy allows the growth of all a person's spiritual powers.

This effect of the opposing forces of moods is important for human life, but it is especially significant for the developing child because the child cannot yet control his or her mood and 
defend himself or herself against negative influences of life's moods. The child is therefore unreservedly at the mercy of the consequences of moods. No one has understood this relationship as deeply as Jean Paul (n.d.a), even if it appears that his writings on pedagogy have failed to gain recognition. "What is 'warmth' for the little child?" he asks in Levana oder Erziehlehre, his teachings about education, and he answers, "Joyfulness! One need only allow room for play-from which reluctance is removed - and all energies naturally flow out" ( $p$. 497). Elsewhere he continues, "Joyfulness ... opens up for the child the circle of constrictions around him ... and allows all youthful energies to arise like morning beams" (p. 503). Even when the adult refrains from engaging in any particular action or certain deliberative intervention, the atmosphere of joy itself is already sufficient for the emergence of impulses and spontaneous activity of play that contribute to the child's growth. "Cheerfulness unlocks, like the springtime, all the inner blossoms" (p. 833). The opposite also holds true. A gloomy and oppressing atmosphere hangs like a musty weight on the child and hinders the child's free unfolding. Jean Paul expresses it well: "In an atmosphere of sourness and exasperation, the malodorous, heavy air chokes all the blossoms of the spirit and morality" (p. 828).

As we look at the child we can discern unique stages and forms of mood here: from the quiet contented chuckle of the nursing child who in total security lies in harmony with his or her surroundings, to the loud joyfulness of child play and the joy in unself-conscious activity, to the risk and acceptance of growing power, through to the busy joy in productive work. Once again, one can discern the various forms of the higher life feelings such as gaiety, joyfulness, happiness, contentment, and salvation. It is possible to differentiate further these life feelings in terms of their individual character, their deeper structure, their varying effects on the child. Each of these life moods makes a unique contribution to the child's growth and must be thought of in this way. Many seemingly senseless pranks or foolish activities that children engage in are really less harmful than some mistrusting child experts suggest, and may in fact contain valuable significances for the fundamental process of child development. Laughter, especially, is to be seen in its positive character. Wherever laughter freely errupts, there is breached the feeling of separation, of contrariness, of reluctance to participate. The child can do nothing else now but join in fellowship and communion. Pitiable, therefore, is the teacher who in his or her suspicion sees every instance of laughter as a sign of mischief. Such a teacher invites, rather than heads off, trouble. 
Mood and life feeling, their relationship and far-reaching consequences for education are seldom acknowledged in educational theory. Yet precisely at this point lies one of the major dangers in the process of bringing up children, especially as it relates to schooling, for it is in the nature of education to be oriented to learning and schoolwork in a conscientious, orderly, and disciplined manner, in contrast to free play which sponsors joyful laughter and other signs of unrestricted childhood which tend to be clumsily smothered by the serious attitude of education. From this educational environment emerges all too easily the atmosphere of listlessness and reluctance, resembling the desolate, spiritless appearance of so many walls of so many schoolrooms, serving to poison every healthy unfolding of the child's spirit.

Gloominess is certainly a job-related illness of the parent or educator-especially of the schoolteacher. The tendency toward this disease is present in the very nature of the teacher's work. If teachers do not want to fall prey to this illness, they must see the danger signs and consciously guard against them, for, to put it simply, only the joyful educator is a good educator. Only an educator who knows the joy of teaching is able to spread joy and encourage youth. I am not suggesting, of course, that a teacher can make such a happy atmosphere. It is not possible to consciously create it, and every attempt at this necessarily will be stultifying. Yet a teacher can carefully cultivate a joyful atmosphere wherever it naturally arises out of the child's experience; or the teacher can share it as its quiet cheerfulness naturally streams forth from the child who is immersed in such happy mood.

I cannot resist calling forth the futuristic vision of the otherwise philanthropist author Salzmann (1785-1788). In a suitably lyrical fashion he presented the dream of an old minister. In this dream people realized that they had ruined and angered their children by using childraising methods which treated children as if they were of the devil. After the adults promised to learn from the children, a heavenly voice ordered all catechisms and vocabulary books which had miseducated children since the beginning of time to be thrown on a large pile. Out of this pile grew a great mountain which was lit,"so that Europe was covered with the light of the flames and the fires of the catechism and the vocabularies." As well "all sticks and rods which had whipped and bloodied innocent children since the beginning of time" were thrown into the fire and their ashes mixed with the ashes of the catechism and the vocabulary 
books. Old and young rejoiced over this. And a beautiful future arose:

All teachers strove to remove their wrinkles which, since the beginning of time, had made their facial features so unfriendly and sullen, and their glances became bright as the sun. And they joined in the lives and activities of children, and played street games with them, chased after balls, and learned to whip and spin tops. The children were thrilled and threw their arms around their teachers' necks, squeezed them and kissed them. (p. 286)

\section{The Sense of "Morning-ness"}

There is another aspect that belongs to a joyful mood. This is a certain temporality - a sense of the joyful unfolding of lived time, which I would like to call "the feeling of morning-ness." I mean to signify the experience of a fresh, happy, forward-looking sense of life-such as one experiences most purely in the early hours of the morning. Runges' evocative engraving, "The Morning," depicts the temporal mood of this awakening sense of life, especially as it is perceived so happily by Romanticism. "The morning, that is my joy," says von Eichendorff (n.d.). This is how it sounds if we want to use the poetic style to render the tone of this joyful mood:

And as a lark singing,

out of a sultry fair

lifts the spirit ringing

into the morning air.

Comparisons between the stage of life of a human being and the time of the day or the season of the year is an ancient practice, but in the past one has rarely asked about the significance that such a characterization of youth has for educating children. Yet this concept of mood seems to be fundamental. Whereas before, joy and childhood happiness were commonly referred to as those types of things which make a positive growing up in the world possible for children, now, on further reflection, they take on a new significance: It is the theme of an active, forceful pull toward the future which is indispensable for human development and therefore also for educating or bringing up children. This feeling of morning freshness is a mood which cannot contain itself but which wants to overflow and which requires an immediate transformation into some powerful application or occupation striving outward, forward, or toward some ideal. I am reminded of the wonderful verse which illustrates exactly this condition of immediacy, when Faust's awakening in the beginning of the Part Two is signalled: 
Life's pulse strikes freshly alive

To softly greet the ethereal Dawning

You, Earth, were also at rest this night

And breathe newly refreshed at my feet.

Beginning already to encircle me with delight

You stir and blend a powerful resolve,

Continually strive towards the highest form of human being.

Notice how striking the transition in Faust is presented from inner bliss which subsequently seems to call forth an outward, upward striving - out of the concreteness of the joyful situation. Thus the morningness of youth is associated with the disposition of acceptance, the making of far-reaching plans, and the hope-filled working toward their fulfillment. Yes, to build castles in the air and to dreamily long for them is natural at this stage.

From this perspective one must try to understand the curious future oriented character of youth; a joyful living into the future, a joyous looking forward to later life which, as something beautiful and promising, awaits the growing young person. It is as if life has given the child a great promise. That is why the young child, in the earliest stage of his or her development, is so receptive to this "newly revealed" world, and that is why the child so willingly and happily allows himself or herself to be engulfed by it. As Jean Paul (n.d.b) says

a fresh pioneering spirit to the world of the new and the original overcomes the child.... The flood of impressions of this first "wonder-world" tends to fill and enchant the receptive interest of the child. All this original goodness is full of unforgettable sweetness and resembles a first love, for it is itself a first love. ( $p$. 822)

This feeling undergoes unique transformations in the individual biography of the person: At first it is the kind of indeterminate and dawning sense of life of the small child; later it turns into the more decidedly forward reaching, future oriented sense of life of the soon-to-be-adult young person.

Even the young child wants to become an adult and speaks with interest of the time "when I'll be grown-up." Later life stands in tempting beauty before the child as a land of promise and longing. With age this attraction becomes more energizing. The growing youth craves the realization of his urge to be useful in the active life of adults, where he or she wishes to enjoy a full sense of responsibility and power to accomplish things. The child wants to be grown up. Therefore, it is a false sentimen- 
should darken this innocence. Even though old age is different, probably best expressed by the notion "evening mood," still it must be doubly careful so as not to drape itself like an oppressive load over the blossoming dreams of youth. But maybe the true educator will never really sink into such an evening attitude of growing weariness because, in his walk through life, he or she lives with children and continues to participate in the morning spirit of youth. As the educator shares their expectations and their dreams, with all their living freshness, he or she is rejuvenated and absorbed by the atmosphere of morningness with them. That is the rejuvenating result of living with children. Frobel (1951) had this in mind when he suggested that there is not just an influence of adults on children, there is also an educationally significant effect from the fresh youthful life of the child onto the weary and worn out adult: "Let them give back to us what we no longer possess: the stimulating power of the child to create" (p. 56).

Of course, not everyone is able to do this. The educator who wants to stay young inside must grow older in a proper way, and this is possible only with great effort and much renunciation. Many achieve this and become better teachers in their older years. (We return to this development when we discuss the virtue of being an older teacher.) Many educators, however, become stuck and sink into grouchy resignation or just plain routine. Therefore, one must seriously raise the question if it is not educationally possible to move, at a certain in time, those teachers who appear to be close to stagnation in their vocation to another calling, even if in earlier years they were good and spirited teachers, so that only those who have properly developed in their career can stay in it. Could we not, for example, make possible a career decision around age 45 which allows this group to be separated from the teaching profession? It seems to me that the organizational difficulties are not insurmountable and that overcoming these difficulties would be highly beneficial. For example, in the various branches of the administration there is enough opportunity to make better use of and to provide greater satisfaction for these highly qualified, well-educated, and experienced people.

\section{The Joy of Expectation}

Within this universally joyful sense of expectation which infuses the child's entire soul, more or less clearly defined expectations become discernible. In addition to the general sense of expectation, these particular expectations also require careful attention by the educator. Children are always full of anticipatory excitement about something great, nice, or beautiful 
that they are looking forward to-something which brings them the future. Human beings always live within the consciousness of what is provisional and tentative, and they tend to turn with their whole soul toward that which is yet to come. If children are not unnecessarily frightened by insensitive and thoughtless parents and siblings who are always threatening "Just wait until you go to school!" then they go to school full of joyful anticipation. They continue to enjoy themselves with every class change of each new subject and joyfully thumb through the pages of each new textbook. The mysterious discussion assignments in the reader, and the incomprehensible pictures in the physics text are all promises of wonderful and challenging things. The child is thrilled to start to learn about them. Proust has shown in a wonderful way how even the sound of the name of a foreign city in geography can conjure up marvelous and mysterious images. And so it is basically with everything that, though as yet ambiguous, lights the way to the child's future fulfillment. As they get older, students may come to the university with a similar joyful (and also somewhat anxious) expectation, ready for yet greater and finer life fulfillments which await them here.

Expectations signify the youthful disposition toward the life to come. Of course, certain expectations sometimes build up a dream-world which cannot truly be fulfilled; disappointments are therefore unavoidable. However, the disappointments themselves may often be unnoticed because in every new situation, new expectations arise which allow the old ones to be forgotten. Nevertheless, the process of suffering diappointments and disillusionments is unavoidable. And with the passing of the years, the power of this joyfully exploring expectation wanes. The future loses its beckoning magic. One expects less and less. In this way human beings come of age.

This development is inescapable, because the illusionary visions of the future necessarily break down with the coming of a different kind of reality. Here arises another important pedagogical problem which is not sufficiently recognized. It is the problem of applying a concern with the significance of expectation to concrete life situations and events-a practical concern which can easily lead to disappointment. Indeed these expectations are bound to disappoint. This will not happen if the confrontation with the other kind of reality takes on a fruitful character, that is, if every new experience is indeed approached as something new-not as something negative but as something enriching, which again gives rise to new expectations. 
That is a task that every person must continually attempt as he or she grows older. The child who is not yet prepared for such a conscious adjustment can be assisted in this through an understanding and caring approach. But unfortunately educators usually care little for this task; they don't even see it, and they have no idea what the expectations with which children confront the future mean for them. Educators are usually oblivious of the often exciting expectations children cherish about new lesson materials, and they tend to plan their curriculum without any considerations - completely independent of what it means for children. This may not matter much if the new material, because of its nature, so captures the child that he or she forgets the earlier anticipations. Yet it is just these neglected and forgotten notions, the child's silent ideas and questions, which connect the new concepts to life in a deeper way. Wagenschein (1962) has shown how in the context of physics education the teacher must first bring children to speak and act with respect to the material being approached before the teacher can introduce them more deeply to the theoretic treatment of the subject.

This is true also of the high expectations with which students usually come to university. Naturally the students' expectations change drastically afterward. But the university concerns itself far too little with these differentiations and assumes that the students themselves will find the new attitudes. What the university could offer is guidance to the beginning students. But even this is usually seen from the view of the demands of the coming faculties and takes little notice of the expectations trustingly brought to the university.

What usually follows is a crisis after several semesters, and it is not necessarily the best students who quickly shift into "the knowledge business" of the university. For a meaningful completion of studies, much more could be done if one paid more attention to the newly arrived students and if one tried to provide them with a better sense of the difference between expectation and reality.

What has been described in these simple situations applies to the health of human life expectations of people in general. In order truly to come to grips with them the educator must first of all know about their existence, which is not easy, for they are usually hidden; often even the child is not fully aware of them. Most of it the educator will have to guess at. Most of all, he or she will have to take hold whenever there are signs of discouragement. The health of the man or woman rests on thisthat he or she is able to find the right balance between the quickly disappearing expectations and their fulfillment, or lack 
thereof. To attempt to assure that this process does not end in unfruitful disappointments is the essential task of pedagogy, and in order to fulfill this task, the educator must first know the effects on the child of his happy expectations. On this basis, he or she will be able to determine a fruitful differentiation between expectations and reality, or at least make suggestions, and be able to lead the child through possible crises.

\section{The Virtues of a Child}

\section{Gratitude and Obedience}

Thus far we have described the basic structure of that feeling of life that is characteristic of children and youth. It is in this general mood or atmosphere that particular attitudes arise which determine the young person's relation with a certain teacher or pedagogue. These attitudes are dependent on this relationship: They are mediated and formed by it. It may also happen that some attitudes are experienced with such special intensity that they extend beyond the feelings of a particular situation and thus influence in turn the total pedagogic atmosphere. Thus the pedagogic relation involves a true interaction and mutual influence between general atmosphere and particular affections. Therefore, the two realms are difficult to separate, for example, the case of the common atmosphere of security, derived from an attitude of trust toward a specific caring person, and without which the sense of security could not even exist.

To this belongs the realm which Pestalozzi (1927) included under the labels of gratitude and obedience. Both are closely related and together encompass the essential element of the child's soul. Today one has become skeptical of these virtues and one asks oneself whether in fact gratitude is even a natural virtue of children. In the stage of growing independence the young person often wants to thank only himself or herself and finds in everything that can make him or her beholden to another person a painful reminder of his or her own dependence and weakness. But this point of view is misleading, because it generalizes the condition of a specific if necessary crisis situation and applies it to the entire condition of childhood. The small child does not yet know anything about this rebellion which experiences the dependence of the world of the adults as a burden. The child experiences the feeling of weakness in a desire for help and protection; it is a feeling of dependence on the world of the adult. But the child does not experience this weakness as a deficiency, because the child is secure in the protection of the adult and he or she trusts the adult in a taken-for-granted need for help. As a matter of course the child 
is thankful for this trust and, therefore, gratitude is included as only a semiconscious feeling-as a component of the child's world which is still an integral world. This is the natural structure of an as yet undisturbed child's life, and the feeling of gratitude is necessarily an element of it. This is the self-evident starting point, and one should not allow one's understanding of the importance of this basic structure to be bothered by the particulars of any later developments and any of the inevitable disturbances of absolutist modern theories.

Just as this integral world must at some time rupture when the young person tries to establish himself or herself, so too this normal gratitude must sunder if the person is to internally consolidate his or her independence. But one must not equate the problems of this crisis - or of other disrupting crises of this time-with the natural, normal state of being; the problem of maturation is resolved as the person returns to a harmonious relationship with his or her environment after the tensions of youth. In this case we say that the child learns again through common sense and good conscience to be thankful. Gratitude of the still developing child, like that of the mature adult, is to be understood in a double sense: on the one hand as a thankfulness toward a specific individual, caring person which extends beyond the activities of raising and educating children into later life; and, on the other hand, as an overarching relationship, as a fundamental feeling of one's entire life in the sense of a faith in a greater whole. This gratitude is not for this or that single gift, but rather a thankfulness for life itself-as gratefulness that one lives, and that in this life one knows that there are loving, helping, and caring people.

Under the umbrella of this general feeling, obedience attaches itself to the particular parent, teacher, or caring adult who gave rise to thankfulness in the child. We are not referring to the kind of obedience which is forced from without, which forces compliance with the law only because one can do nothing else. Rather, we mean the quiet, natural obedience which is not even experienced as such because it arises as a matter of course in an accommodating, orderly world. Here, behind any acquiescence to some command or request stands a common spiritual foundation, namely the trusting readiness of the child to accept the request with a joyful affirmation and to identify with it.

Yet this childlike obedience is not acknowledged today as something natural or self-evident. At present, one assumes that obedience means hardship for the child and, one tries to spare the child from it if possible. But this view, which sees only possible inferiority complexes and aggressive tendencies in the 
child, misunderstands again the foundations of the development of a normal, healthy child. Children may experience themselves as small and in need of help (smaller and more vulnerable than the grown-ups) yet only in cases of pathological growth does a consciousness of inferiority arise-in the child namely only if the natural relation of oneness with the adult is disturbed. Otherwise the child is drawn toward the adult, feels united with the adult, and participates in the adult's greater strength. It willingly fits itself into this life with its embodied orderliness, and out of this natural fitting-in arises the willing and joyfully acquiescing obedience which is simply there, without any complex problems. Only against this background can one understand the minor, defiantly awakening desire for individuality and independence. Of course, these feelings may occur. But the point is that they are not the predominant mood. One notices them because they occur as happenings against the background of healthy obedience. Children themselves do not feel good about disobedience, and they are glad when they can come back into life again.

In my view, this fundamental condition of obedience of the child is a most important and necessary prerequisite of educating and bringing up children. It requires attention and care, because it is only through a sense of obedience that the child grows into the order of the common world. Thankfulness and obedience, as fundamental conditions of childhood, are essentially complementary and inseparable: Only in the thankful approach to the adult arises the free, true, inner-acquiescing obedience; and only in such an obedient self-reconciliation is the feeling of thankfulness perfected.

In any case, both thankfulness and obedience can be signified as natural preconditions only in the early years of childhood. Later they must necessarily fracture if the child is to arrive at independence through the crisis of maturation. The pedagogically problematic nature of this process, how it is most pressing during puberty and how it is meaningful and necessary as such, is not the issue here. But we must continually be aware that all instances of disobedient and ungrateful withdrawal of the young person are to be understood as deflections arising out of the normal condition. Thankfulness and obedience remain a continuing passage. And educators must forever set themselves the fundamental task of restoring this original pedagogic atmosphere; for pedagogy cannot succeed without fulfilling these preconditions. Ungrateful individuals, as long as they remain in this state, cannot be cared for. It may be difficult to free them from this mode of being, and it may very often be momentarily 
unpleasant. Therefore, the parent or educator must have great patience in order to keep clear sight of his or her goal despite all failures. However, without fail, this condition of thankfulness and obedience will be experienced by children as fortunate when, after tensions and hardships, they find themselves again in a reconciled relationship.

There is still another distinction to be made. We note the merely temporary nature of our overcoming of difficulties during the time of self-developing independence; we have said already that ungratefulness is not a simple error which must be condemned outright, rather it is something which springs out of a proud will-an attempt to live in complete independence without the need to owe anyone gratitude. Similarly, disobedience is not simply an error to be corrected; rather, it is the necessary stage through which one must pass to arrive at an independent and responsible life. Adults, too, find themselves in situations where, because of a deep sense of responsibility, they must choose to be disobedient. But behind the alternating passage of constant acts of guiding and accepting the youngster in that rich atmosphere, slowly the consolidating vision of the adult being begins to stand out and these difficulties begin to fade.

It is clear that the pedagogical significance of thankfulness and abedience is most valid only for a specific age of childhood. The problem of obedience loses significance as soon as the youth graduates from the sphere of childhood into the domain of free determination and appreciation. From the attitude of obedience which arises out of a sensitive communion with a particular person there freely develops an acceptance of a positive order of things-cultural, political, or of whatever nature. Therewith obedience ceases to be an expression of an all-encompassing approach to living; rather, it becomes merely a response to one situation or another. Order and obedience are seen as distinct in one sense, and yet they are recognized as necessary aspects of an arrangement.

At this point arises the problem of authority. I have reservations about speaking of the authority which parents and educators are supposed to have over the young child, for as the parents are experienced as (more or less) omniscient and all powerful by the child, so the particular person and the general sense of power are still grasped as undivided by the child. Only if the sense of personal power and the sense of absolute power are separated, and if the teacher or parent becomes the embodiment of a sense of order which is larger than this teacher or parent and with whom they are no longer identifiable, then the adult can assume appropriate authority. Depending on differing circumstances 
this authority can take on different forms: scientific authority, the authority of human or cultural achievement, and so forth.

Thus the problem of authority may lose its sense of gravity and finally disappear; this does not apply in the same way to thankfulness. Above all we are dealing here with a much deeper, more slowly developing kind of maturation which reaches into a later stage, and which causes the older person to approach the childhood state again, where the various distinct experiences of gratitude blend into an all-encompassing, general attitude of gratitude. The person then is no longer merely thankful for this or that act of helpfulness, for this or that gift; rather, he or she is grateful for the very gift of a life which, despite times of sorrow, is experienced as an undeserved gift.

\section{Love and Adoration}

Love and adoration also belong to gratitude and obedience. Now the child's love is something we do not need to say much more about-it is that total, natural attachment and emotional attraction to those who are close. Love belongs to the realm of self-evident and fundamental conditions of human life, while in the pedagogical relation it acquires the special form of that "upward glance"; it is that totally trusting, all believing love. It signifies, in particular, the relationship to the parents and often, in a special sense, to the mother.

Despite the sense of communion which is obviously inherent in the child's upward glance, adoration is clearly to be distinguished from love. Adoration lacks the immediate warmth and taken-for-grantedness of love. It is already a stance apart, an objective observing and therefore a cooler (not necessarily less intense) relationship. Adoration appears pedagogically especially in the relationship to the teacher but it is not necessarily tied only to the personal educational situation. Often those whom we know through their works or their achievements can become objects of our adoration.

And within the notion of adoration itself one can perceive many variations of form, depending on the nature of the educational situation and the age of the developing child. The list extends from the naive trust of the small child in the invincibility of the father, to the zealous commitment of the teenager to the idolized peer leader, to the matter-of-fact wonderment over the overwhelming knowledge of the adored teacher. Even the fanaticism of young people for any commercially sponsored idol, such as a rock star, belongs to this category. We cannot in this space fully explore the differences between the many variations of adoration which have found their way into our language 
(Bollnow, 1947). We must be content merely to take up a few of the threads which come to hand.

Sentiments of adoration (admiration, devotion, veneration, adulation) are necessary characteristics of a productive educational environment, even in the case of ordinary classroom teaching. Children have a special need; they want to admire and honor their teacher. They want to feel a sense of awe over the knowledge and competence of the teacher; they want to admire the teacher's strength of character and feel awe for what it is that makes an adored teacher stand out. This concerns not just the teacher's actual subject-matter knowledge but more the fact that the teacher is seen to have so much knowledge-it is this kind of sentiment which essentially readies the child to learn from the teacher. Children want to be proud of their teacher and feel themselves to be lifted by the special relationship which each child can personally experience. Therefore, children do not really rejoice in the failures or weaknesses which they discover in their adversary, their friendly, challenging teacher; rather, they feel distressed. Children tend to want to learn, but they are prepared to learn without resistance only from a teacher who deserves their respect and adoration. Therefore, the real learning situation is essentially dependent on these "atmospheric" and "sentient" conditions.

This is even more true for the moral development and character formation of the child. The feeling of adoration awakens in the child a desire to stand victorious before the honored person and to be acknowledged by this significant person. That is a strong motivation to strive harder. It is a powerful, forward-pushing force. There awakens at the same time the need for an inner agreement or correspondence with the interpretations and ideals presented by the teacher or this significant adult, and this leads to the process of appropriation. Yes, much of what is initially taken to be merely affection for the teacher will later on still be fruitful. Thus the adoring affection opens the child to the influences of the educator. The childlike sentiment to take part in the beckoning flight of the inspired and inspiring young teacher is another example of one of those fertile pedagogical relationships.

Here we have not spoken about one feeling, which one might have expected, and that is the value of awe. This may seem all the more surprising in that Goethe (1949), in the well-known passage in his "Pedagogic Province" has given us such a wonderful and enlightening presentation of bringing up children with a sense of awe. But as Goethe saw so sharply, awe and respect come to the person not from within, but rather it is 
carefully nurtured through a long and protracted process of education and socialization, or it must be acquired through the process of personally painful experiences. That is why it is missing here, where the discussion is about natural sentimental preconditions of childrearing and education. Awe is not one of these primary preconditions; rather, it is the result of a long period of development.

\section{Note}

Translated and edited by Max van Manen and Peter Mueller from O.F. Bollnow (1962/1970), Die Pädagogische Atmosphäre, (5th ed.), Heidelberg: Quelle und Meyer Verlag (permission from publisher).

\section{References}

Arndt, E.M. (1912). Werke. (L. Band, hrsg. von A. Leffson und W. Steffens). Berlin: Deutsches Verlagshaus Bong.

Bollnow, O.F. (1947). Die Ehrfurcht. Frankfurt a.M.: Verlag V. Klostermann.

Bollnow, O.F. (1955). Neue Geborgenheit. Das Problem einer Überwindung des Existentialsmus. Stuttgart: Verlag W. Kohlhammer.

Bollnow, O.F. (1963). Mensch und Raum. Stuttgart: Verlag W. Kohlhammer.

De' Medici, L. (1825). Opera. I. Firenze.

Frobel, F. (1951). Menschenerziehung. Ausgewählte Schriften. (2 Band, hrsg. von E. Hoffmann). Bad Godesberg: Verlag Helmut Kupper.

Goethe, J.W. (1949). Gedenkausgabe. (5 und 8 Band, hrsg. von E. Beutler). Zürich: Artemisverlag.

Heidegger, M. (1927). Sein und Zeit. Halle a.d. Saale: Verlag M. Niemeyer.

Herbart, J.F. (1887). Allgemeine Pädagogik. Samtliche Werke. (2 Band, hrsg. von K. Kehrbach).

Jean Paul. (n.d.a). Levana oder Erziehlehre.Werke. (hrsg. von E. Berend. 5 Band). Berlin: Propylen-Verlag.

Jean Paul. (n.d.b). Bruchstuck aus der "Kunst, stets heiter zu sein." Werke. (hrsg. von E. Berend, 5 Band). Berlin: Propyläen-Verlag.

Kant, I. (1922). Werke. (8 Band, hrsg. von E. Cassirer). Berlin: Verlag B. Cassirer.

Langeveld, M.J. (1954). L'endroit secret de l'enfant. Situation. Beitrage zur phänomenologischen Psychologie und Psychopathologie. Utrecht-Antwerpen: Verlag Spectrum.

Nitschke, A. (1962). Das verwaiste Kind der Natur. Ärztliche Beobachtungen zur Welt des jungen Menschen. (hrsg. von A. Nitschke. Forschungen zur Pädagogik und Anthropologie. 5 Band). Tübingen: M. Niemeyer Verlag.

Nohl, H. (1967). Ausgewählte pädagogische Abhandlungen . Paderborn: Ferdinand Schöningh. 
Pestalozzi, J.H. (1927). Sämtliche Werke. (hrsg. von A. Buchenau, E. Spranger, H. Stettbacher, 13 Band). Berlin: Verlag Walter de Gruyter.

Rilke, R.M. (1930). Gesammelte Werke. (3 Band). Leipzig: Insel-Verlag.

Salzmann, C.G. (1785-1788). Carl von Carlsberg oder Uber das menschlich Elend. (6 Bände). Frankfurt a.M. und Leipzig.

Von Eichendorff, J. Freiherr. (n.d.). Werke. (hrsg. von R. Dietze). Leipzig: Bibliographisches Institut.

Wagenschein, M. (1962). Die pädagogische Dimension der Physik. Braunschweig: Verlag Westermann. 